\section{CAUSE OF THE NEW HAMPSHIRE EARTHQUAKES OF 1940}

$\mathrm{L}$

D. LEET has made an important contribution concerning the beginnings of the New Hampshire earthquakes of December 20 and 24, 1940, in the Ossipee Mountains district ("Mechanics of Earthquakes where there is no Surface Faulting", by L. Don Leet, Bull. Seis. Soc. America, 32, No. 2; April, 1942).

On the basis of the travel-time data on elastic waves from the Ossipee earthquakes, combined with the results of Griggs's experiments on rock deformation and fracture, Prof. Leet proposes the following hypothesis. A zone of radius roughly $20 \mathrm{~km}$. initially unstrained and spherical, extending upward into the crustal layers to near the base of the granitic layer, was progressively distorted by a horizontal shear couple. When the strain reached a critical value for the material, fracture occurred near the original sphere's equator and was the source of the largest shear waves. Distortion by pure shear transformed the original sphere into an ellipsoid, which terminated short of the earth's surface, where fracture had to grade into folding and die out. At the upper terminus of the resultant ellipsoid's major axis, this process would produce a concentrated compressive force on the base of the granitic layer, which started the longitudinal waves. This implies simultaneous mass movement of translation of the upper half of the original sphere. The resultant compressive stresses developed in the granitic layer kicked back four days later and produced the second earthquake. The aftershocks died quickly, in part because of rapid healing of the fractures and in part because the region was brought practically to equilibrium by the second shock, since relief carne in zones of flow which, unlike surface faults, have few, if any, irregularities to produce temporary frictional hang-ups as movement progresses. If this is true, the probability is that the Ossipee structure does not extend below the base of the granitic layer, for otherwise a mass movement of the plug, which is an important feature of the White Mountains structure, would have been expected to show up at the surface.

The evidence of recent years is definitely that regional forces are at work on new levels of activity in the north-eastern American province. No great stretch of imagination is required to detect an alignment of some of this activity, including the earthquakes of December 1940, along the trend of the major reservoir for the White Mountains magma series. On grounds of distribution alone, however, there does not seem to be a satisfactory basis for distinguishing between deep-seated magmatic forces in renewed activity and yield to glacial loading stresses along old planes of weakness.

\section{APPOINTMENTS VACANT}

APPLICATIONS are invited for the following appointments on or before the dates mentioned:

DePuty ENgineer ann MaNager of the Southport and District Water Board-The Clerk to the Southport and District Water Board, Town Hall, Southport (September 14).

FULLY QUALIFIED FOUNDRYMAN to act as SUPERINTENDENT in the College Instructional Foundry-The Registrar, Loughborough College, Loughborough.

\section{FORTHCOMING EVENTS}

\author{
Friday, September 11
}

PHYsicaI, SOCTETY (Colour Group), at Imperial College, S.W.7, at 2.30 p.m. Mr. E. G. Savage: "The Teachin)
(Lecture followed by informal discussion).

\section{REPORTS and other PUBLICATIONS} (not included in the monthly Books Supplement)

\section{Great Britain and Ireland}

Why Hitler? By H. Runham Brown. Pp. 20. (Enfleld : War Resisters' International.) $3 \bar{d}$.

Proceedings of the Royal Society of Edinburgh. Section A (Mathematical and Physical Sciences). Vol, 61, Part 3, No. 16: Simultaneous Linear Partial Differential Equations of the Second Order. By E. L. Ince. Pp. 195-209. (Edinburgh and London: Oliver and

Scientific Proceedings of the Royal Dublin Society. Vol. 23 (N.S.), No. 2: The Chemical Constituents of Lichens found in Ireland, Cladonic Pp. 5-10. (Dublin : Hodges, Figgis and Co., Ltd. ; London: Williams Pp. 5-10. (Dublin : Hodges, Figgis and Co., Ltd. ; London: Williams
and Norgate, Ltd.) $6 d$. Geological Map of the British Islands, based on the Work of the Geological Survey. Third edition. Scale of 25 Statute Miles to 1 Inch 36 in. $\times 26 \frac{1}{2}$. (Southampton: Ordnance Survey Office.) Uncoloured, 18.; coloured, 28.; mounted and folded in sections, 48. net. [208

\section{Other Countries}

Proceedings of the United States National Museum. Vol. 92, No 3141: Scored Bone Artifacts of the Central Great Plains. By W. R. Wedel and A. T. Hill. Pp. 91-100+plates 7-13. Vol. 92, No. 3143: The Sardis (Georgia) Meterite. By E. P. Henderson and C. Wyth Cooke. Pp. 141-150. Vol. 92, No. 3144: Rhopocrinus, a New Fossil Inadunate Crinoid Genus. By Edwin Kirk. Pp. 151-155 + plates 16. (Washington, D.C.: Government Printing Offee.) [317 Publications of the Allegheny Observatory of the University of Publications of the Allegheny Observatory of the University of
Pittsburgh. Vol. 8, No. 6: The Field of Epsilon Lyrae. By Esther M. Pittsburgh. Vol. 8, No. 6: The Field of Epsilon Lyrae. By Esther M.
Doody and Keivin Burns. Pp. 77-90. (Pittsburgh, Pa. : University Doody and Keivin Burns. Pp. 77-90. (Pittsburgh, Pa.: University
of Pitsburgh Press.)

U.S. Department of Agriculture. Technical Bulletin No. 823: Strains of Field Corn Resistant to the Survival of the European Corn Borer. By L. H. Patch, J. IR. Holbert and R. T. Everly. Pp. 22. (Washington, D.C.: Government Printing Office.)

Smithsonian Institution. War Background Studies, No. 1 : Origin of the Far Eastern Civilizations, a Brief Handbook. By Carl Whiting Bishop. (Publication 3681.) Pp. 53+12 plates. (Washington, D.C.: Smithsonian Institution.)

Indian Forest Records, New Series. Utilization, Vol. 2, No. 6 : The Thermal Conductivity of Indian Timbers, Part 1: Variation of The Thermal Conductivity of Indian Timbers, Part 1: Variation of Tonductivity with Density in the Air-Dry Condition at Ordinary Temperature. By D. Narayanamurti and V. Ranganathan. Pp. iil t
150-167. (Delhi: Manager of Publications.) 9 annas; 10d.

Indian Central Jute Committee. Technological Research Memoir No. 4: Tests on Commercial Jute Yarns. By C. R. Nodder. Pp. ii +25 . (Calcutta: Indian Central Jute Committee.) 1.4 rupees 28. $3 d$. $[128$

Annual Return of Statistics relating to Forest Administration in British India for the Year 1939-40. Pp. iii +31. (Delhi : Manager of Publications.) 2.14 rupces ; $48.9 d$.

[128

Colony of Mauritius: Department of Agriculture. Twelfth Annual Report of the Sugarcane Research Station, 1041. Pp. 31. (Port Louis Government Printer.) 40 cents.

[138

Some Remarks on Desert Sand-Storms. By F. W. Oliver. (Printed for the Desert Committee under the sanction of the Ministry of Agriculture.) Pp. 16. (Alexandria: Whitehead Morris (Egypt), Ltd.)
[13.T.2. Report of the Botanical Survey of India for 1940-41. Pp. 188 (Delhi: Manager of Publications.) $[138$

Records of the Botanical Survey of India. Vol. 6, No. 10: Useful Plants of Mayurbhanj State in Orissa. By S. N. Bal. Pp. xii $+119+$ Plants of Mayurbhanj State in Orissa.
xx. (Delhi: Manager of Publications.) 4.14 rupees; $78.9 d$. [138 Forest Bulletin No. 102 (Chemistry, New Series): A Note on the Active Principles of Embelia robusta, Roxb., Myrsine semiserrata, Wall., and $M$. capitellata, Wall. By S. Krishna and B. S. Varma. Pp. 4. (Delhi : Manager of Publications.) 3 annas; $4 d$. [138 Indian Forest Records, New Series. Entomology, Vol, 7, No. 3: On the Biology of the Noctuida (Lepidoptera). By R. N. Mathur. Pp. ii $+74-154+1$ plate. (Delhi : Manager of Publications.) 2.4 rupees ; $38.9 d$.

Imperial Council of Agricultural Research. Miscellaneous Bulletin No. 52: Milk Recoras of Sahiwal Cows in Approved Dairy Farms in India. Vol. 3 (Records received during 1938-40). Compiled by the Animal Husbandry Bureau, Imperial Council of Agricultural Research Pp. ii +50 . (Delhi : Manager of Publications.) 3 rupees; 58. [138 Forest Research Institute. Indian Forest Leaflet No. 18: Somc Factors affecting the Quality of Charcoal for Producer Gas Plant. By S. Ramaswami. Pp. ii +6 . (Dehra Dun : Forest Research Institute.)
4 annas; $6 d$.
[148 